\title{
DETECTION OF MYCOPLASMAS IN CULTURES OF MYELOMA. CELL LINES AND HYBRIDOMAS BY FLUORESCENCE METHOD. USING VERO CELLS AS INDICATORS
}

\author{
O. FISCHER, Marta GRANÁTOVÁ, Marie HÁJKOVÁ, Zora NEVORÁNKOVÁ, \\ Květoslava JURMANOVÁ
}

Veterinary Research Institute, 62132 Brno

Received December 19, 1989

\begin{abstract}
Fischer O., Marta Granátová, Marie Hájková, Zora Nevoránková, Květoslava Jurma nová : Detection of Mycoplasmas in Cultures of Myeloma Cell Lines and Hybridomas by Fluorescence Method Using Vero Cells as Indicators. Acta vet. Brno, 60, 1990: $41-49$.
\end{abstract}

Four myeloma cell lines and four hybridomas were examined for the presence of mycoplasmas by the fluorescence method using bisbenzimide 33258 (Hoechst). The cell suspensions under examination were cultivated for 3 days together with Vero cells as indicators and then examined by fluorescence microscopy. Mycoplasma contamination was detected in 2 myeloma lines. The results were confirmed by culture methods and by scanning electron microscopy.

Mixed cultures, bisbenzimide, scanning electron microscopy

Fluorescence (Chen, 1977) is often used for the detection of mycoplasmas and other contaminant microorganisms in cell cultures. The method is based on chemical bound of the fluorochrome bisbenzimide 33258 (Hoechst) to DNA. The fluorescence microscopy visualizes not only nuclear DNA of the examined cells, but also DNA present in the contaminant microorganisms.

In our laboratory, routine examinations of monolayer cell cultures using fluorescence method by Chen (1977), modified by Machatková et al. (1986) are performed. In correctly stained. preparations, only the nuclei of examined cells and organellae of contaminant microorganisms. containig DNA show bright, greenish-yellow fluorescence. Weak fluorescence, sometimes observed in the cytoplasm of examined cells is considered to be an artifact. Mycoplasmas and bacteria are the most frequent contaminant microorganisms, but we have demonstrated that mould and yeast: contaminations are also detectable by the fluorescence method (Fis cher et al. 1989).

While the fluorescence method is reliable and, above all, much faster than culture methods for the examination of monolayer cell cultures, it cannot be used for direct examinations of semi-suspension cultures of myeloma cells and hybridomas. Staining with bisbenzimide results in a very intensive fluorescence of myeloma and hybridoma cells and fluorescence of the much smaller contaminant microorganissms can be overlooked easily (Smirnova and Fridlyanskaya 1985). Regarding the threat of mycoplasma contamination of myeloma cell lines and hybridomas maintained in our laboratory (Granátová et al. 1988), we tried to detect mycoplasms in these semi-sus-pension cultures by the fluorescence method using Vero cells as indicators.

\section{Materials and Methods}

Myeloma cells and hybridomas (Table 1) were cultured in an open system in Heraeus thermo-. stat at $37^{\circ} \mathrm{C}$ in an atmosphere containing $5 \% \mathrm{CO}_{2}$. The medium RPMI 1640 (ÚSOL, Prague). supplemented with nonessential amino acids (USOL, Prague) was used. The content of an ampule was added to $1000 \mathrm{ml}$ medium containing $2 \mathrm{mM} / \mathrm{ml} \mathrm{L}$-glutamine, $2 \mathrm{mM} / \mathrm{ml}$ sodium pyruvate, $40 \mu \mathrm{g} / \mathrm{ml}$ gentamycine and $10 \%$ bovine fetal serum (Cooperative farm, Sokolnice). Before reseeding, the cells were released from the walls of Mueller flasks by agitating. The reseeding ration was $1: 3$.

Vero indicator cells (ATCC.CCL 81), isolated from kidney of Cercopithecus aethiops, were cul- 
Table 1

Examination of semi-suspension cultures using fluorescent method with Vero cells as indicators

\begin{tabular}{|c|c|c|c|}
\hline & \multirow[b]{2}{*}{ Culture } & \multicolumn{2}{|c|}{ No. of samples } \\
\hline & & examined & mycoplasma \\
\hline Myeloma line & $\begin{array}{l}\mathrm{FO} \\
\mathrm{P} \text { 3/NS 1/1-Ag-4-1 } \\
\text { P3X63Ag8 } \\
\text { Sp 2/0-Ag 14 }\end{array}$ & $\begin{array}{r}6 \\
15 \\
6 \\
15\end{array}$ & $\begin{array}{l}6 \\
0 \\
6 \\
0\end{array}$ \\
\hline Hybridoma & $\begin{array}{l}\mathrm{C} / \mathrm{C} 10 \\
\mathrm{C} / \mathrm{D} \\
\mathrm{C} / \mathrm{E} \\
\mathrm{C} / \mathrm{F} \\
\mathbf{C}\end{array}$ & $\begin{array}{l}10 \\
10 \\
10 \\
10\end{array}$ & $\begin{array}{l}0 \\
0 \\
0 \\
0\end{array}$ \\
\hline Control Vero & & 30 & $\mathbf{0}$ \\
\hline
\end{tabular}

itured in a closed system in Mueller, Legroux and Roux flasks at $37^{\circ} \mathrm{C}$ in the antibiotic-free medium M-199 (ÚSOL, Prague), supplemented with nonessential amino acids and $10 \%$ bovine fetal serum. No antibiotics were used. Before reseeding, the cells were released enzymatically with a solution containing $0.2 \%$ trypsin and $0.02 \%$ versene. The reseeding ratio was 1:3-6. All employed cell cultures were frozen using the two-step method as described by Pěknicová and Landa (1985). Hybridomas were thawed using BALB/c mouse peritoneal cells as a support (Granátová et al. 1988).

Prior to examination the Vero indicator cells were seeded into test tubes containing pieces of slides $5 \times 20 \mathrm{~mm}$ and $2 \mathrm{ml}$ culture medium. The cells were seeded at a density producing only an incomplete monolayer within 3 days of incubation. A dense suspension of examined cells $(0.1 \mathrm{ml})$ was added to the test tube following 1-2 hours of cultivation, when the Vero cells were attached to the slide and flattened. Suspension density was set to obtain a thick coverage of the piece of slide and a close contact between the examined and the indicator cells.

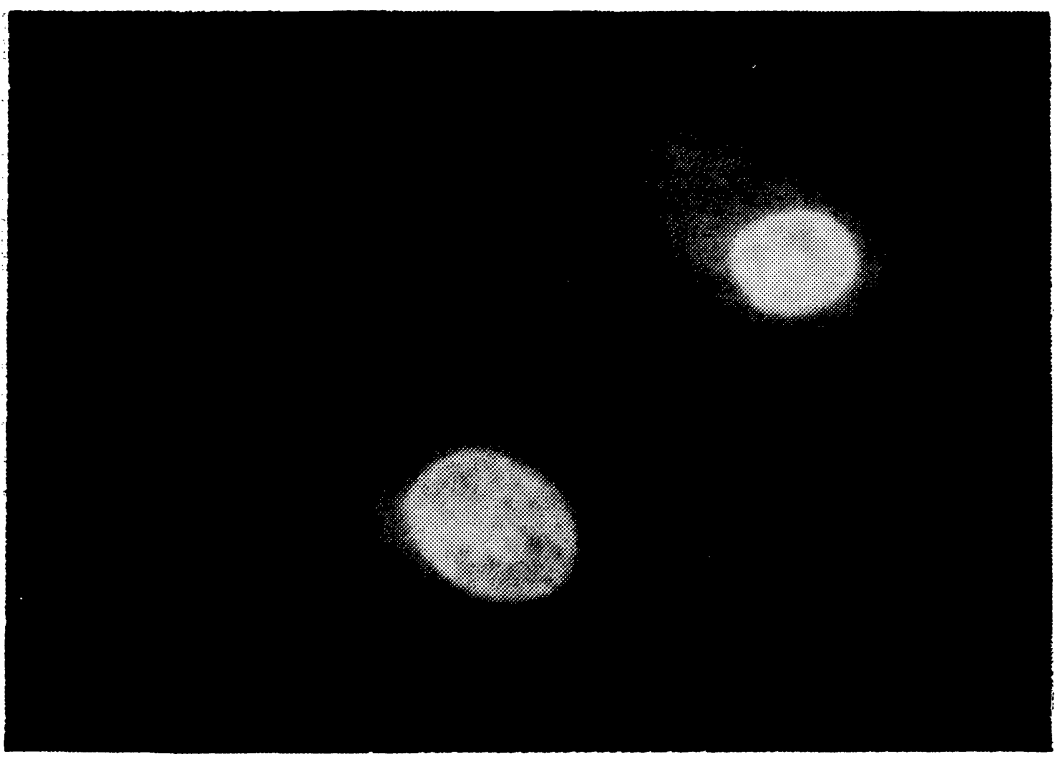

Fig. 1 Fluorescing nuclei of Vero cells surrounded by weakly fluorescing cytoplasm. Fluorescence of cytoplasm is considered to be an artifact (bisbenzimide 33258; magnification $252 \times$ ). 


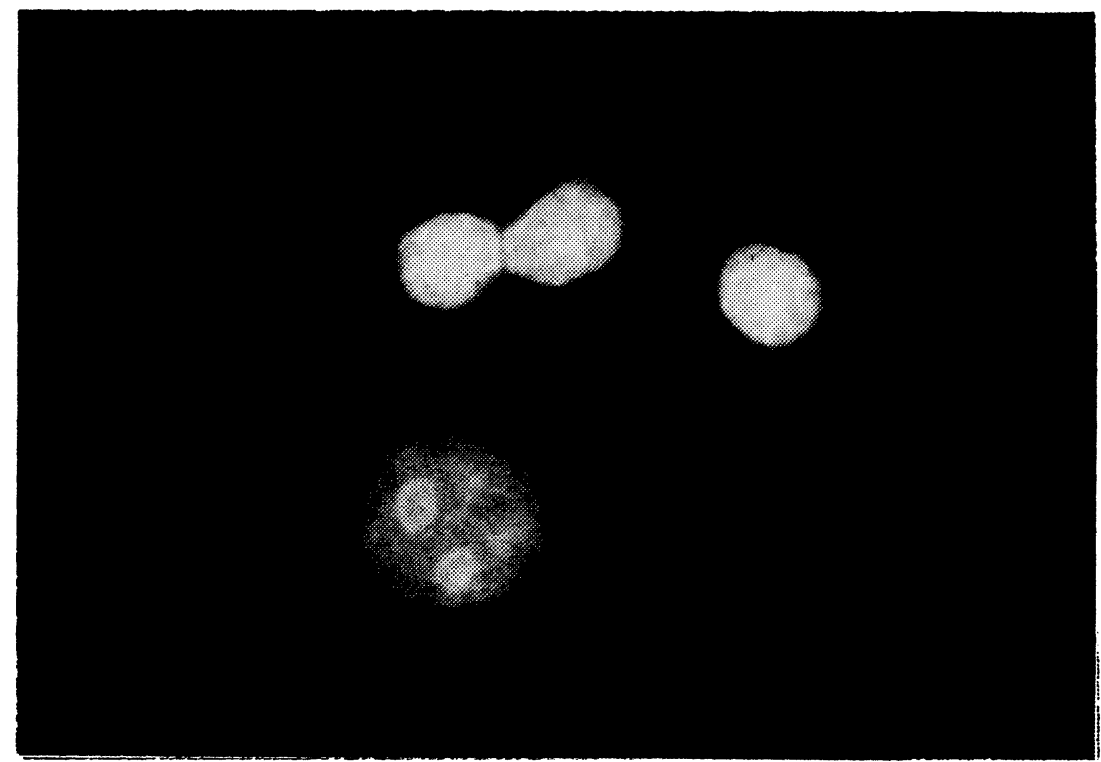

Fig. 2 One fluorescing nucleus of a Vero cell and three cells of the myeloma line Sp 2/O-Ag14 bisbenzimide 33258; magnification $252 \times$ ).

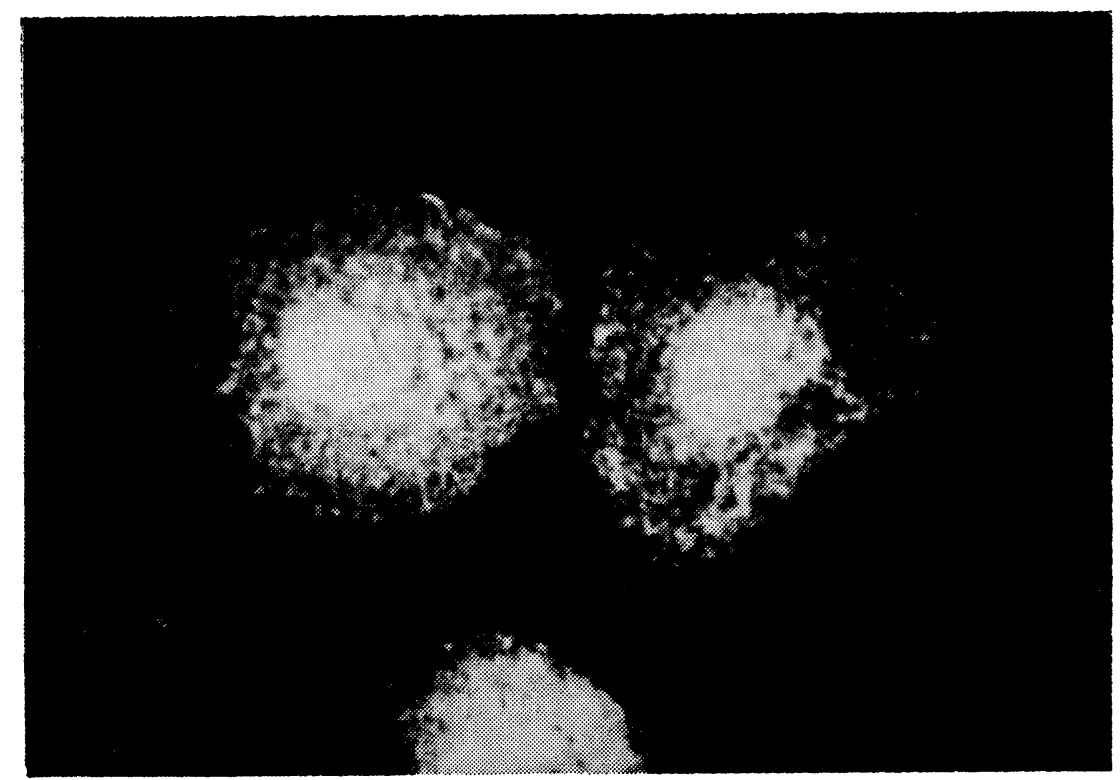

Fig. 3 Nuclei of Vero cells and brightly fluorescing mycoplasmas (bisbenzimide 33258, magnification $252 \times$ ). 
The mixed culture of examined and indicator cells was incubated in tubes with a slope of $15^{\circ}$, at $37^{\circ} \mathrm{C}$ for 3 days. Thereafter, the slides were rinsed with isotonic phosphate buffer (PBS, pH $6.5-6.8$ ) and the cells were fixed in methylalcohol for $15 \mathrm{~min}$. Slides with fixed cells were air-dried, stained with $0.001 \%$ solution of bisbenzimide 33258 (Hoechst) in methylalcohol for $10 \mathrm{~min}$., then washed in bidistilled water and mounted into glycerine buffer ( $\mathrm{pH} 5.5)$ as described by Machatková et al. (1986).

Indicator cells grown on slides for 3 days, without the addition of examined cells, were fixed and stained in the same way, and used as controls.

The preparations were examined by fluorescence microscopy at a magnification of $252 \times$.

For the examination by scanning electron microscopy, the slides with cell cultures were rinsed with PBS, the cells were fixed with $3 \%$ solution of glutaraldehyde for 20 min., rinsed 3 times with distilled water, dehydrated in acetone series $(30,50,70,90 \%$, pure and absolute acetone), dried at critical point and coated with pure gold. Coated preparations were examined by scanning electron microscope Tesla BS 300, at magnifications $1000 \times, 10000 \times, 15000 \times$.

Mixed and control cultures were examined by culture methods using liquid and solid media for mycoplasma cultivation (Jurmanová et al. 1983).

\section{Results}

No contamination with mycoplasmas was detected in the myeloma lines $\mathbf{P}$ 3/NS 1/1-Ag-4-1, Sp 2/0-Ag14 and in hybridomas by fluorescencè, scanning electron microscopy or culture methods. Neither mycoplasmas nor other contaminant microorganisms were found in control cultures of indicator Vero cells.

Severe contamination with mycoplasmas, confirmed by culture, was detected in samples of mixed cultures Vero + FO and Vero + P3X63Ag8.

Intensive greenish-yellow fluorescence of nuclei and micronuclei and occasional weak fluorescence of cytoplasm was observed in uncontaminated Vero cells and

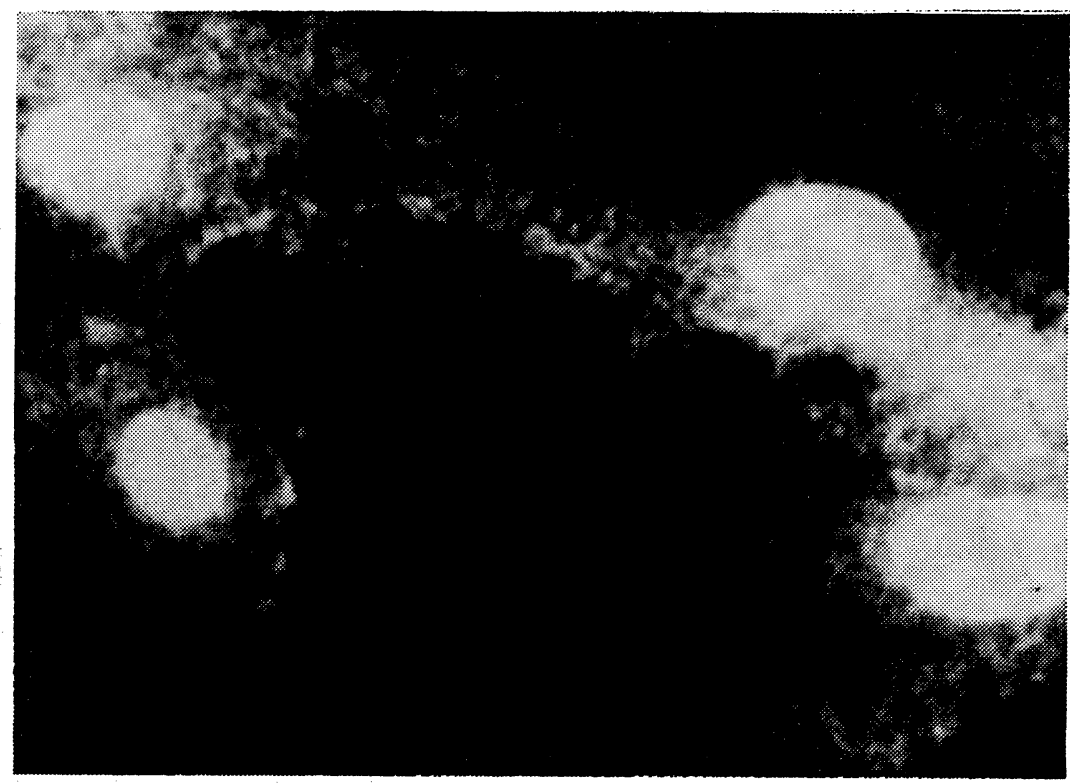

Fig. 4 Nuclei of Vero cells and brightly fluorescing mycoplasmas (bisbenzimide 33258, magnification $252 \times$ ). 
is considered to be an artifact (Fig. 1). In addition to Vero cell nuclei, myeloma and hybridoma cells adhering to the slide and not rinsed away by PBS, were seen in uncontaminated mixed cultures (Fig. 2). Numerous small, brightly fluorescent bodies were observed (Fig. 3 and 4 ) on the surface of Vero cells, which were cultured together with myeloma line FO or P3X63Ag8 cells. Cells of contaminated myeloma lines were mostly released from the slides during cultivation.

Marked differences between the surfaces of contaminated and uncontaminated Vero cells were revealed by scanning electron microscopy. While only fine microvilli (Fig. 5) were noticeable on the surface of uncontaminated cells, numerous spherical and oval bodies, sometimes with small central depressions, and filamentous structures were observed on the surface of Vero cells cultured together with contaminated FO or P3X63Ag8 cells (Fig. 6).

\section{Discussion}

Mycoplasmas were detected in 2 myeloma lines by the fluorescence method. These findings were confirmed by culture and scanning electron microscopy.

The ability to bind with DNA, thus making it detectable by fluorescence microscopy, is possessed not only by bisbenzimide 33258 (Hoechst), but also by bisbenzimide 33217 (Hoechst) used in the U.S.A. (ATCC Quality Central Control Methods for Cell Lines, 1985), the antibiotic olivomycin (Mikhailova et al. 1982; Polster 1986) and by DAPI (4'-6-diamidine-2-fenylindol) a trypanocide similar to Berenil (Russell at al. 1975).

Machatková et al. (1986) have simplified the original method (Chen 1977) and adapted it to the conditions of our laboratory.

Compared with culture, the fluorescence method offers several advantages: only killed material is used, the method is more rapid and the results are independent of properties of microorganisms, which may be influenced by culture conditions and antibiotics. Culture methods might fail if cells cultures are contaminated by mycoplasma strains, which are difficult to cultivate (Polak - Vogelzang et al. 1980).

Previous experiments have shown a single culture examination by the fluorescence method is not reliable, especially in case of contamination by small quantities of microorganisms (unpublished data).

Small contaminant microorganisms, as are mycoplasmas, are well visible on a dark background only, therefore the monolayer should not be dense. Otherwise small mycoplasmas adjacent to larger cell nuclei can be easily overlooked.

It is necessary to distinguish between the fluorescent microorganisms and the artifacts: fluorescent cytoplasm, fragments of nuclei, chromosomes of dividing cells and residues of culture medium. Microorganisms that are not attached to the slides can be rinsed away with a stream of PBS before fixation.

The incubation period of 3 days for the mixed cultures of the examined and indicator cells was chosen to let mycoplasmas and other contaminant microorganisms propagate and to make them more easily detectable. Our previous studies have shown that mycoplasmas propagate very rapidly in nutrient-rich media, modified by the presence of metabolites of the propagating cells, especially if antibiotic-free media are used for the cultivation of indicator cells (unpublished data). 


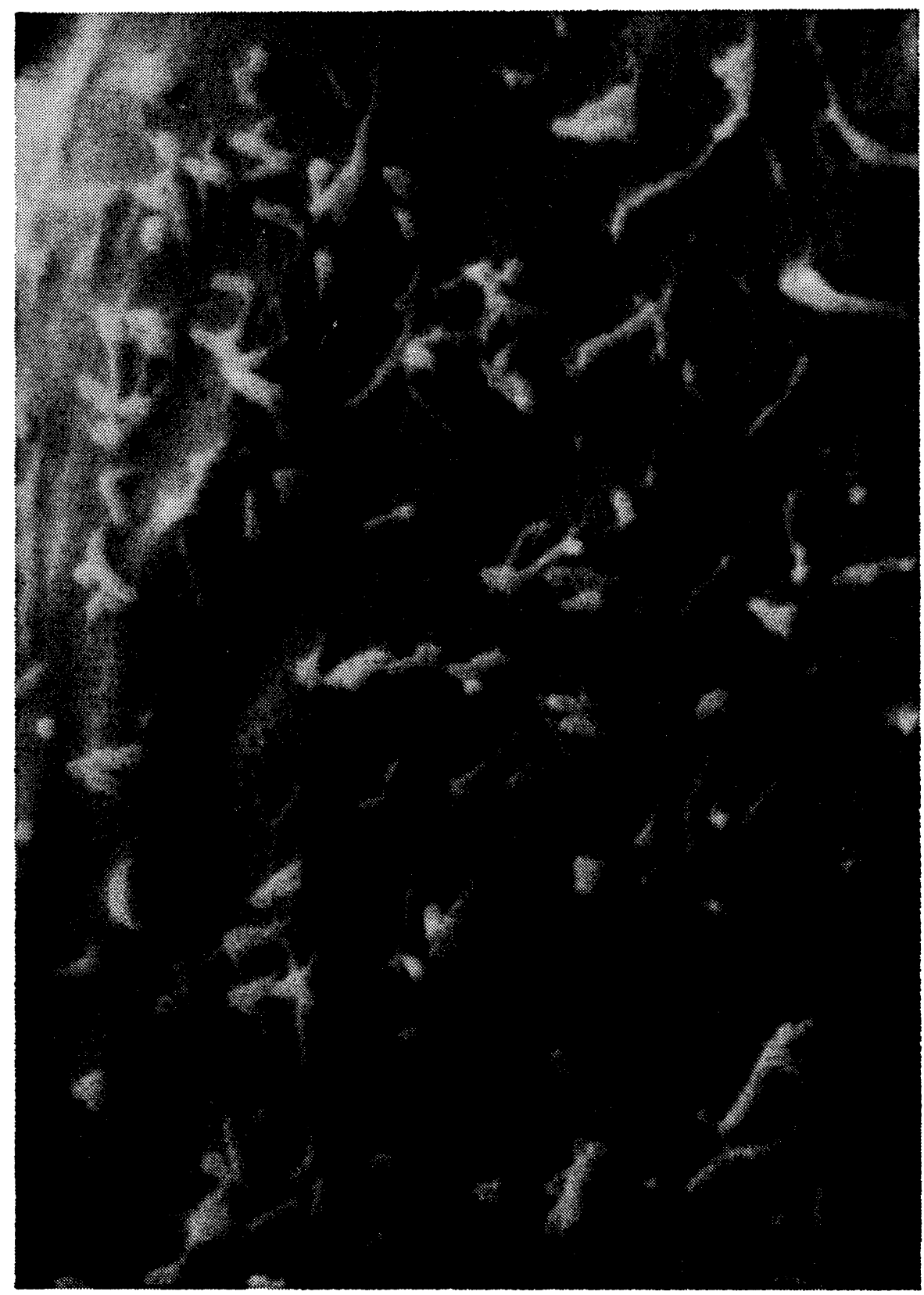

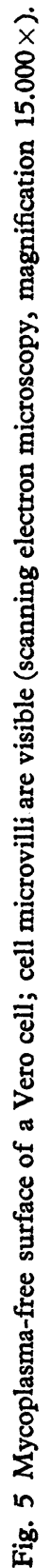


Jurmanová and Machatková (1986) used Vero cells as indicators for mycoplasma demonstration in serum samples.

Vero cells are suitable for this purpose, because they are not too sensitive to. acid production in medium and because they form long projections on which. mycoplasmas attach readily if cell density is not too high.

As stated by $\mathrm{Hay}$ et al. (1989) in their review, Swiss albino mouse fibroblasts: 3T6 (ATCC.CCL 96) can also be used as indicator cells besides Vero cells: (ATCC. CCL 81).

The appearance of numerous, minute, intensively fluorescing bodies on cell surface corresponds to the descriptions and photographs of mycoplasmas published by Machatková et al. (1986) and Calorini and Ruggieri (1989).

Maul (1987) pointed out difficulties in distinguishing between filamentous forms of mycoplasmas and cell microvilli. Brown et al. (1974), using scanning electron microscopy, described mycoplasmas as spherical or oval formations: with a diameter of $0.35-0.8 \mu \mathrm{m}$, but filamentous or even ramified forms of mycoplasmas were observed, too.

Regarding the fact that minute forms of mycoplasmas can be hardly distinguished from cell microvilli, we do not consider the scanning electron microscope as a suitable tool for mycoplasma detection in cell cultures.

The examination of semi-suspension cultures, using the fluorescence method with Vero cells as indicator is relatively rapid, as the preparation of samples including cell cultivation takes only 3-4 days and does not require the use of expensive materials.

Zjištování přítomnosti mykoplazmat v kulturách myelomových linii a hybridomů fluorescenční metodou s použitím indikátorových buněk. linie Vero

V kulturách 4 myelomových buněčných linií a 4 hybridomů byla fluorescenčnf́ metodou s použitim bisbenzimidu 33258 (Hoechst) zjištována prítomnost mykoplazmat. Vyšetřované buněčné suspenze byly po dobu 3 dnů kultivovány společně s indikátorovými buňkami linie Vero a pak vyšetřovány fluorescenční metodou. 2 myelomové linie byly kontaminovány mykoplazmaty. Výsledky byly potvrzeny kultivačními metodami pro záchyt mykoplazmat a rastrovací elektronovou. mikroskopií.

Выявление наличия микоплазм в күльтүрах миеломных пиний и гибридомов флюоресцентным методом с применением индикаторных. клеток линии Веро

В культурах 4 миеломных клеточных линий и 4 гибридомов методом: флюоресценции с применением бисбензимида 33258 (Hoechst) выявляли наличие микоплазмы. Исследуемые клеточные суспенсии культивировали в течение 3 дней совместно с индикаторными клетками линии Веро с последующим исследованием флюоресцентным методом. Две миеломные пинии отличались контаминацией микоппазмами. Результаты подтвердили методами күльтивирования для задержки микоплазмы и растровой электронной микроскопией. 


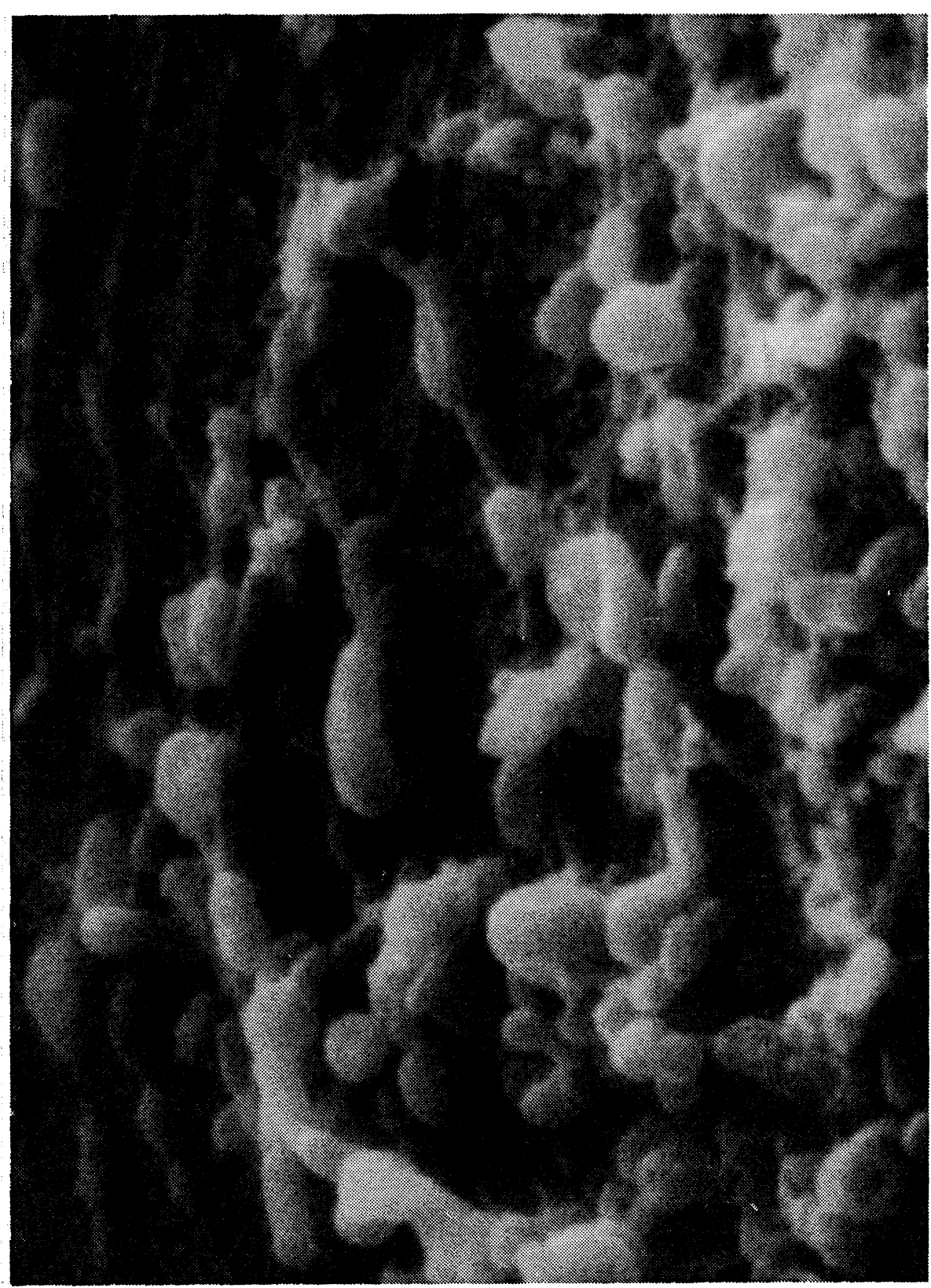

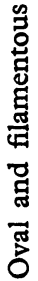

官

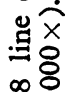

舟足

గ్రి명

ผ

零嵒

4

焉

品

요

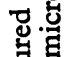

胥

긍면

हี్ㅀㅇ

$\circ \stackrel{b 0}{0}$

언.

$>$ ב

पै

\& \&

莺苛

0

它 


\section{Acknowledgements}

We express our gratitude to Mr. Jiři Kudrna, Mr. Zdeněk Pospišil and Mr. Miloš Hornich for photographic assistance and to Mrs. Favla Valošková for arrangement of the manuscript.

\section{References}

ATCC quality central control methods for cell lines, 1st ed., Rockville, ATCC 1985, 81 p.

BROWN, S.-TEPLITZ, M.-REVEL, J. P.: Interaction of mycoplasmas with cell cultures, as visualized by electron microscopy. Proc. nat. Acad. Sci, U.S.A., 71, 1974: 464-468

CALORINI, I.-RUGGIERI, S.: Eradication of Mycoplasma contamination from cell lines of ditierent origin by the 5-bromouracil-fluorochrome procedure. Cancer Letters, 46, 1989: $107-112$

CHEN, T. R.: In situ detection of mycoplasma contamination in cell cultures by fluorescent Hoechst 33258 stain: Exp. Cell Res., 104, 1977: 255-262

FISCHER, O.-GRANÁTOVA, M. - NEVORÁNKOVA, Z. - HORINOVA, Z. -RUBEŠ, J.URBANOVÁ, J. - JURMANOVÁ, K. - HÁJKOVÁ, M. - KOSKOVÁ, S. - VAL IĆEK, L. POSPISIL, Z. - HORNICH, M.: Charakteristika vybraných buněčných linií uložených v bance bunéčných kultur. (Project report.) Brno, Veterinary Research Institute 1989, 31 p.

GRANÁTOVA, M.-RODÁK, L.-VESELY̛, T. - NEVORANKOVA, Z. - MUSILOVA, J.: Zvládnutí metod hybridomové techniky. (Project report.) Brno, Veterinary Research Institute $1988,31 \mathrm{p}$.

HAY, R. J.-MACY, M. O.-CHEN, T. R.: Mycoplasma infection of cultured cells. Nature (London), 339, 1989: 487-488

JURMANOVA, K.-MACHATKOVA, M.: Detection of mycoplasmas in cell cultures and biologicals. Arch. exp. Vet. Med., 40, 1986: 136-141

JURMANOVA, K.-MACHATKOVÁ, M. - HÁJKOVÁ, M. - CERNÁ, J. - CHLUPOVA, L.: Detekce mykoplazmat v buněčných kulturách. (Project report.) Brno, Veterinary Research Institute 1983, $31 \mathrm{p}$.

MACHATKOVA, M.-JURMANOVÁ, K.-HAMPL, J.-SNEJDAR, V.: Spontánní infekce buněčných kultur mykoplazmaty a její detekce fluorescenční metodou. Vet. Med. (Praha), 31, 1986: $447-485$.

MAUL, G.: Positive detection of mycoplasma contamination by the whole mount preparation of cell cultures for transmission electron microscopy. J. Bact., 133, 1978: 1 452-1 456

MIKHAILOVA, G. P. - NOVOKHATSKYI, A. S. - RODOVA, M. A.: Novyi sposob vyyavlenia mikoplazm v perevivaemykh kulturakh kletok. Vopr. Virusol., 27, 1982: 759-761

PĚKNICOVA, J.-LANDA, V.: Two-step freezing of cells used in hybridoma technology. Folia biol. (Praha), 31, 1985: 340-347

POLAK-VOGELZANG, A. A.-REYGERS, R.-HEKKENS, F. E. N.: Isolation of Mycoplasma hyorhinis and Mycoplasma fermentans from cell cultures. J. Biol. Standard., 8, 1980: $243-254$

POLSTER, U.: Der fluoreszensfärberische Nachweis von Mykoplasmen in Zellkulturen mittels Olivomycin. Arch. exp. Vet. Med., 40, 1986: 142-146

RUSSELL, W. C. - NEWMAN, C. - WILLIAMSON, D. H.: A simple cytochemical technique for demonstration of DNA in cells infected with mycoplasmas and viruses. Nature (London), 253, 1975: $461-462$

SMIRNOVA, T. D. - FRIDLYANSKAYA, I. I.: Kontaminacia kletotchnych kultur mikoplazmami: metody obnaruzhenia i vozmozhnye puti rasprostranenia mikoplazma-infekcii. Citologia, 27, 1985: 276-281 